\title{
Making minority faith (in)visible through religious education: parents' experiences of the identification of their children's Orthodox identity in Finnish public schools
}

\author{
Pekka Metso $^{1}$
}

Published online: 8 February 2019

(C) The Author(s) 2019

\begin{abstract}
The focus of this article is on parents' experiences with and perceptions of their children's religious education (RE). The data consist of letters from 41 parents of Finnish Orthodox children and youth. In the letters, the parents describe their understanding of minority religious upbringing and how it is affected by different factors like RE. RE is a mandatory subject in Finnish schools, and it is taught in groups consisting of children with the same religious backgrounds. The main questions in this article are (1) how do the parents view the arrangements for Orthodox RE to make their children's minority religious affiliation visible at school, and (2) what is the effect of RE on the formation of their children's minority identity? The analyses show that parents perceive RE as an important factor in their children's identity formation. Despite the sometimes inadequate arrangements for Orthodox RE in school, the parents are mostly happy with the subject and with their children's RE teachers. RE makes the minority religious affiliation of Orthodox children both visible and invisible: their difference from the majority is exposed, but minority RE classes often take place outside of regular school hours and even outside of school premises.
\end{abstract}

Keywords Religious education · Orthodox Christianity · Religious minority · Identity · Finland

\section{Introduction}

Today, the space given and created for religion in public schools, and the nature of RE are contested in many European countries (see e.g. Franken and Loobuyck 2011; Jäggle et al. 2014). Themes relating to the interaction of European educational policies and practices between public spaces and religion was just recently elaborated in the special issue of the Journal of Religious Education (September 2018). Based on that issue, there seems to be a need for more research on how RE and religious socialisation interweave in schools, not only in RE classrooms, but more broadly (cf. Ubani

Pekka Metso

pekka.metso@uef.fi

1 School of Theology, University of Eastern Finland, P.O. Box 111, 80101 Joensuu, Finland 
and Ojala 2018). In this article, the complex subject of the interplay between RE and religious socialisation is studied from the perspective offered by a specific group and context: Orthodox minority RE in Finnish public schools.

Since the current law on freedom of religion that came into force in Finland in 2003, RE has been non-confessional, yet pupils receive RE according to their own religion if their denomination is registered in Finland. Thus, non-confessionalism is linked to the religious background of the pupil and RE groups are formed according to the pupil's religion. In Finland, RE is a compulsory subject both in comprehensive school and in upper secondary school (for children 7-18/19 years of age). The content of RE classes are based on each particular religion, but the students study other religions and worldviews as well (Kallioniemi and Ubani 2012; Lyhykäinen 2009; Sakaranaho 2006, 2008; Ubani 2013b, pp. 69-72).

In Finland, the debate on religion's place in education has, since the beginning of the twenty first century, focused on two questions: why are children of different religious backgrounds taught separately instead of in one RE group, and should RE be included in the curriculum in the first place (Korkeakoski and Ubani 2018; Ubani 2013b, pp. 69-84; Åhs et al. 2019)? While isolated schools have acted progressively and put children of different backgrounds into one group, representatives of minority religious groups have expressed their disapproval against any attempts that endanger the current system (Iivonen 2009; Korkeakoski and Ubani 2018; Sakaranaho 2007). Of the churches involved in the debate, the Orthodox Church of Finland has actively pursued securing Orthodox RE as an independent subject and attested that the prevailing system meets the demands of the Orthodox population (Leo 2010a; Yhteinen katsomusopetus ei saa kannatusta 2015). The main argument for not making alterations to the current RE system has been safeguarding the identity of religious minorities and supporting genuine multiculturalism in an almost entirely homogeneous Lutheran country (Leo 2010b, 2012, 2015; Okulov 2011).

Since Finland gained independence in 1917, the Finnish Orthodox Church has enjoyed the status of the second national or 'state' church in Finland, after the Evangelical Lutheran church. Orthodox Christianity is still the biggest Christian group after the majority Evangelical Lutheranism in Finland, comprising ca. 1.1\% of the population with ca. 61,000 members (in 2017). Despite official recognition by the state, the Finnish Orthodox population has often faced social pressure to hide their religious traditions, and at least until the late 20th century, oftentimes seen by the majority as strange and even un-Finnish (Aikonen 2012, pp. 63-64; Laitila 2008; Berglund 2014).

In this article, I study how the minority position and identification of Finnish Orthodox children and youth emerges through RE. I approach this theme through parents' experiences and perceptions by focusing on the following questions:

- How does their children's minority religious affiliation become visible in the school?

- What kind of effect does RE and the school community have on the formation of their children's (minority) identity, and what factors contribute to this?

Answering these questions enables us to point out how minority identification in the social context of the school takes place both from outside (in relation to and by the non-Orthodox majority) and from within (in and through the Orthodox RE group). 


\section{The data and methodology}

The sources for this study consist of letters written by 41 parents of Finnish Orthodox children. The letters were received between March and June 2014 as the result of an open invitation published in major Finnish Orthodox parish and diocesan magazines. The invitation was also circulated on Facebook by some parents, and at least one parish published it on its website. In the invitation, parents of Orthodox children and youth were asked to write about their understanding of and experiences with religious parenting, of the aims and contents of their religious upbringing, and about factors that contribute to their religious parenting or that are a hindrance to it.

The exact number of letters received was 39, since two letters were written and signed by both parents. The majority of the participants were women (36). A substantial amount of other information was not comprehensive enough, since many parents did not reveal accurate personal information. Based on the available information, however, approximate figures can be given. The age of the participants varied from 30 to 70 years, with the majority being in their 30 s or 40s. Except for two mothers, one Bulgarian and the other presumably Russian, the parents were of Finnish origin. In regard to church affiliation, most participants described themselves as Orthodox. However, at least four parents were Lutheran and one had no church affiliation (civil register).

Methodologically, I have used content analysis in analysing the letters. I carried out the analysis inductively, relying on the content: Parents' experiences, attitudes, and knowledge of RE and its role in their children's identity formation was examined and thematically and theoretically reconstructed from the data.

Based on the same data, I have already published a study on how the minority status of the Finnish Orthodox affects their religious upbringing at home (Metso 2018). The study reveals that certain elements in school are disturbing religious parenting at home:

1. Teachers' lack of respect toward children's Orthodox convictions

2. Inadequate practical arrangements for RE classes

3. Poor quality of RE classes

4. Lack of orthodox peers in the classroom/school

The results indicate that belonging to a religious minority can be a complicated matter, and that there are some problems in how minority RE is currently organised in Finnish schools. In this article, I dig more deeply into parents' experiences with RE.

The headings of each sub-section in Sect. 4 refer to focal findings, emerging from the data as an outcome of my analyses, on the key theme of the identification of minority religion in the school community (from outside) and in RE groups (from within). In Sect. 4.1, I study how the parents describe their children's encounters with the majority religious culture in their schools (in the context of RE and generally). In Sect. 4.2, I focus on how arrangements for Orthodox RE resonate with the minority position of Orthodox children. Finally, in Sect. 4.3, I examine the relation between identity formation and RE as described by the children's parents. Before engaging with the analyses of the data, the arrangements for Orthodox RE are described in Sect. 3 in more detail, and themes arising from the research on minority RE are also discussed. 


\section{Religious minority RE}

\subsection{Arrangements for minority RE in Finland}

The website this is Finland, maintained by the Finnish Ministry for Foreign Affairs, offers basic information on things one should know about Finland. One important need-to-know fact is how religious education (RE) is organised: it is a mandatory subject in school that is taught to children in groups organised based on their religious backgrounds. Instead of being confessional per se, the aim of RE is to instruct children in their own religion, consequently guaranteeing the rights of minorities and respecting their convictions. Furthermore, RE supports the development of children's identities and promotes intercultural dialogue in Finnish society (Ministry for Foreign Affairs 2010; see also Kallioniemi and Ubani 2012).

In Finland, there are currently 13 different National Framework Curricula for different religious groups ${ }^{1}$ and one for secular ethics or 'life perspective studies'. Statistics from 2014 reveal that of the children in elementary education, 91\% attend Evangelical Lutheran RE, the dominant religious tradition in Finland (ca. $70 \%$ of population belongs to the Lutheran Church). Approximately 5\% attend life perspective studies, the non-religious alternative to RE, which is currently the second-largest convictional group. The secondlargest religious group with ca. $2 \%$ attendance is Muslim RE, while $1.5 \%$ attend Orthodox (Christian) RE, and the remaining $0.5 \%$ represent other smaller religious minority RE groups (Sakaranaho 2018; Uskonnonopetus Suomessa 2016).

From the perspective of religion's role in public space, the state of Finland clearly recognises the importance of religion (and convictions in general) in the public sphere and respects children's specific religious background in schools. As Sakaranaho (2018) observes, 'fostering plurality of RE is seen from the state's point of view as a benevolent gesture of recognition towards different religious communities.' Sirpa Okulov, the Coordinator of Education of the Orthodox Church, has characterised the principle of teaching children's own religion as 'ambitious and biased in favour of minorities' (Okulov 2014).

\subsection{Orthodox RE in Finnish public schools}

Orthodox RE has been taught in Finnish schools more or less systematically since the late 1860s. Compared with other newer minority RE curriculums, it has an established status and history in the Finnish educational system. Schools have to organise Orthodox RE if there are at least three Orthodox pupils in the area of one municipality (Berglund 2014; Sakaranaho 2018). The minimum requirement for forming an Orthodox RE group is met in the majority of the schools in Finland. In 2012, 65-70\% of schools had an Orthodox RE group, with the number of Orthodox pupils attending totalling 7371 (Esitys perusopetus- ja lukiolain muuttamisesta 2014).

Orthodox children in the same school usually form one RE group. Often, children in nearby schools are brought together to form a larger group. RE teachers face the challenge of incorporating curricula for different classes simultaneously and supervising a heterogeneous group consisting of children of different ages-and increasingly,

\footnotetext{
1 Evangelical Lutheran, Orthodox Christian, Muslim, Catholic, Jewish, Buddhist, Christian Community, Latter Day Saints, Free Church, Adventist, Baha'ì, Hare Krishna and Herran Kansa (the Lord's People in English, a small free church community) (Zilliacus and Holm 2013). .
} 
of different languages and cultural backgrounds (Berglund 2014; Huurinainen-Kosunen and Lyhykäinen s.a.). In contrast, this is a good chance to foster group spirit and Orthodox identity when otherwise separate Orthodox pupils come together and form one group around a subject common only to them (cf. Okulov 2011). As the study by Tuutti and Vainio (2007) indicates, for Orthodox pupils with non-Finnish backgrounds, a small RE group that mixes pupils with Finnish backgrounds is highly positive and contributes to their integration (cf. Rissanen 2014; Ubani 2013a; for the integration of non-native Muslim pupils through RE in Sweden, see Berglund 2010).

In the National Framework Curriculum (2014), the goal of Orthodox RE is to offer elements that help to build pupils' personal worldviews and their ethical growth through knowledge, skills and experiences. The goals of Orthodox RE include strengthening and supporting Orthodox identity, and broadening pupils' understanding of their own religious tradition and other religions. Central to the perspective of identity formation is the objective of enabling pupils to deepen their religious minority (Orthodox) identity (Aikonen 2012; Berglund 2014). A study on Finnish Orthodox RE teachers' concepts of the aim of RE $(n=94)$ indicates that teachers follow the guidelines for Orthodox RE. They see supporting children in life questions and value choosing as well leading and confirming their own religion as the main aims of RE (Lyhykäinen 2009).

The National Framework Curriculum reflects dimensions of religious identity as conceptualised by Hemming and Madge (2012). They itemise four dimensions of religious identity: (1) affiliation and belonging, (2) behaviours and practices, (3) beliefs and values and (4) religious and spiritual experiences. The Finnish system of RE seems to incorporate at least the three latter dimensions, but it leaves the question of religious practice aside.

The majority of Orthodox pupils consider RE to be a meaningful and rewarding subject. In 2016, a national survey $(n=234)$ of Orthodox pupils' attitudes toward RE reveals that $60 \%$ of respondents feel that RE helps them to understand their own values, and 58\% think that RE helps them to understand differences among people. If the pupils were given the chance to participate in 'general' RE (i.e. in a group of pupils with different religious backgrounds), $62 \%$ of Orthodox children stated that they would rather have their own RE group, and $44 \%$ would not want to attend 'general' RE at all (Oppilaskysely ortodoksisesta uskonnonopetuksesta 2016). A smaller survey $(n=97)$ conducted in the metropolitan area of Helsinki shows that Orthodox pupils appraise Orthodox religion as forming the core of their RE (Lyhykäinen and Smalin 2008).

If Orthodox pupils are more or less happy with their RE, their parents appreciate it even more. Surveys by Hyvärinen $(n=201$ parents) and Vatanen $(n=222$ families $)$ among parents of Orthodox pupils reveal that they see RE as a necessary school subject that supports their children's identity and broadens their worldview. The parents especially appreciate the core contents of Orthodox RE in the national curriculum, the competence of the teachers and teaching in small groups (Hyvärinen 2014; Vatanen 2000).

Religious instruction at home is diminishing in Finland, and parents tend to give more responsibility for it to the church and school (Pessi and Pöyhönen 2010, pp. 32-33). Due to a lack of longitudinal research among Orthodox parents, possible changes to the educational responsibilities among the Orthodox population cannot be verified. Nevertheless, existing studies show that parents view co-operation with school and an Orthodox congregation as essential (Hyvärinen 2014; Loikala 2015). The Orthodox Church encourages parents to take care of their children's participation in Orthodox RE despite occasional problems with arranging RE (Oman uskonnon opetus 2018; Uskonnonopetus kouluissa 2018). 


\subsection{RE and minority identity formation}

Of the research on how pupils experience minority RE in Finland, the most substantial piece is a study by Zilliacus (2014), who found that minority pupils generally have a positive experience with their own RE group and RE as a school subject. At the same time, pupils report negative experiences in feelings of difference in relation to the Lutheran majority. Sakaranaho's $(2006,2008)$ research on pupils' experiences in minority RE and ethics classes has similar results. Several other studies among children with non-Finnish backgrounds have shown that there is a relationship between integration and attending minority RE classes. Their own RE groups, most often Islam or Orthodox RE, provide children with non-Finnish backgrounds with familiar elements of their religious and cultural backgrounds, thus strengthening their sense of security and enhancing integration (Alitoppa-Niitamo 2002; Berglund 2014; Rissanen 2014; Sakaranaho 2006; Tuutti and Vainio 2007).

$\mathrm{RE}$ teachers of minority religions tend to expect that the religious background of their pupils is a uniting element. Due to the teacher's valuation of a strong religious identity, pupils with a weak affiliation with their religious tradition may feel uncomfortable in the classes (Zilliacus 2013; Zilliacus and Holm 2013). On the other hand, as a recent study (Ubani 2018a) on pupils' experiences with integrated RE (students from Lutheran RE, Orthodox RE, and secular ethics) shows, especially Orthodox students felt accepted during integrated lessons. Thus, Ubani argues that the claim that students from minority RE do not feel welcome in integrated RE is unfounded.

Studies in other contexts and different education systems suggest that belonging to a religious minority is a factor that strongly affects children's navigation within their school community. A study by Dupper et al. (2015) in public schools in the United States indicates that school environments make children's minority status visible but also vulnerable, bringing negative attention to them. Religious minority students may be marginalised if they choose not to comply with the norms of the majority. Consequently, as Forrest-Bank and Dupper (2016) suggest, dialogue between peers and exchanging knowledge is a way for children of religious minorities to successfully navigate religious differences among their peers. A study by Torstenson-Ed (2006) suggests that exposure to religious diversity fortifies children's religious identity instead of threatening it.

However, it is not an easy task to encompass religious diversity in school. A study on Muslim RE in Finland and Ireland indicates that despite the aim of integrating Muslims into the system of education and supporting religious freedom through RE, preference is often given to teaching Christian traditions, and native Finnish and Irish (often non-Mus$\mathrm{lim}$ ) teachers are favoured at the expense of non-native teachers (Sakaranaho 2018; see also Ubani 2018b).

Much of identity formation, socialisation and education on religion in society, both of pupils of minority and majority religious and cultural backgrounds, takes place outside of the RE classes. As stated by Ubani and Ojala (2018), in the social sphere of school, 'RE is just one agent in the interplay of formal and informal education concerning the place and representation of religion in public life.' Encountering and educating children in religion in schools has a broader social impact. Especially for families belonging to a religious minority, school represents the entire society. Thus, experiences of equality and feelings of belonging in the society are shaped by the attitude that schools have toward minorities. Based on this, people judge how their religion, language and customs are tolerated, accepted and welcomed in the society (Huttunen 2018). 


\section{Parents' experiences of Orthodox RE}

\subsection{Encountering the majority tradition enhances minority identity awareness}

The Lutheran church has ruled the Finnish religious sphere since the 16th century. For historical and cultural reasons, the Lutheran tradition is present in many facets of Finnish society, culture and public space; this applies to school as well. Lutheran traditions, beliefs and church are something that all pupils encounter in one way or another in basic education (i.e. integrated primary and lower secondary education) and high school (i.e. upper secondary education). In 2000s, however, the justification and value of certain Christian (Lutheran) traditions has been discussed publicly in Finland. The most heated debate has focused on Christmas traditions (i.e. nativity scenes, plays and hymns), religious morning assemblies and singing Suvivirsi (Summer Chant or Spring Chant in English), a Lutheran hymn that is deeply established within Finnish culture, on the last day of school before summer vacation. The reasons for critically re-evaluating Finnish religious heritage include declining church membership, weakened commitment to Christianity and increased multiculturalism within Finnish society. Even if the presence of Lutheran beliefs and rituals no longer goes unquestioned, they still have a strong foothold in the festive traditions and weekly schedules of Finnish schools.

Quite unsurprisingly, the presence of the Lutheran tradition in school emerges in my data as well. The parents of Orthodox children do not necessarily see contact with the Lutheran tradition as either positive or negative-rather, they describe a certain liminality in these encounters with the Lutheran tradition. Their personal stance toward Orthodox and Lutheran churches, their children's experiences and the specific realities in classrooms and schools all affect their assessment of their children's (and their own) minority status as well as their attitude toward the presence of the Lutheran tradition in school. The effect of school education on Orthodox Christian children's identities is captured in this description given by a mother of three:

In school at the latest [is when] a Finnish Orthodox child becomes aware of belonging to a minority. Obviously, the child comes up with many questions, and not later than in this phase he will begin to compare himself with others. There are certain risks in this, but due to discussions brought up [in the family], it is for the good [of the child]. - - - I would like my child to perceive himself foremost as a Christian, not becoming a 'super-Orthodox', but at least by the first grade one must begin to outline boundaries of what is Orthodox and what is not. (Elisa)

This account exemplifies the complexity and sensitivity of the effects of being exposed as belonging to a minority in a school community. Going to school, Elisa suggests, is a sociological and existential turning point that inevitably makes it clear for Orthodox children that they are different from the other students-not only their school mates in the classroom, but with respect to the majority of the Finnish population. Orthodox children's and other children's reactions influence how exposure of religious affiliation affects children's identity. Elisa expects her child to be active in defining his Orthodoxy with respect to diversity in the classroom: to demarcate practices and patterns of behaviour based on their conformity with Orthodox convictions.

Lutheran RE in Finnish society is sometimes referred to as 'normal' or 'ordinary', thus suggesting that minority religion RE is somehow 'abnormal' or 'extraordinary' (Lyhykäinen 2009; Okulov 2011, pp. 191-192). A study on minority RE groups in Finnish 
schools reveals that even though an own RE group is generally seen as a positive thing, pupils still experience feelings of otherness and lack a sense of community. They also feel a negative sense of difference in relation to the pupils in the majority Lutheran RE (Zilliacus and Holm 2013). In my data, seven parents explicitly mention that being Orthodox among other non-Orthodox children has engendered discussions at home on identity: what it means to be Orthodox, what kinds of faiths and beliefs other people have and what is the Orthodox understanding of certain issues (e.g. venerating icons, homosexuality and priesthood). In addition to these explicit mentions of family talks, accounts of several other parents indicate that they are also aware that being Orthodox in a school community necessitates processes of re-evaluating one's identity.

The data suggest that instead of radical segregation, parents of Orthodox children encourage them to remain faithful to their Orthodox faith while adapting to the rest of the class, and ultimately, the society. As one mother summarises, Orthodox children (and the Orthodox population in general) need to develop the skill of cultural literacy:

Cultural comprehension includes polite tolerance, and at the same time, appreciation of [one's] own culture, questioning its attributes and discussing things that are a part of it. (Ulla)

Accordingly, tolerance is mentioned most often as the value parents hope their children will adopt from Orthodoxy. Appreciation of peaceful coexistence between people of different worldviews, cultural backgrounds and beliefs may originate not only from the core teachings of the Orthodox faith, but also from the conditions of belonging to a minority. As one mother puts it, being different from her friends and the dominant population due to her Orthodoxy has helped her to better understand people's differences and has significantly shaped her aims for her children's religious upbringing:

I wish such tolerance for my own sons, and I try to educate them accordingly so that they will smoothly tolerate difference because they themselves are 'different'. (Irene)

Even if the parents acknowledge their children's existential and social processes brought about by becoming more aware of their Orthodoxy, their general approach to the majority Lutheran tradition can be labelled as neutral. This neutrality manifests itself as complying without problems with the existing cultural realities of Finnish society, the dominant Lutheran faith being a part of this. The data reveal that parents of Orthodox children as a rule find it natural that their children attend Christmas worship and other Lutheran events in school with the other pupils.

At least a few parents are aware that it is not obligatory for Orthodox (and other nonLutheran) children to take part in Lutheran religious activities at school. They let their children decide whether or not they would like to attend Lutheran events. There are no indications of parents aiming to restrict their children's attendance of non-Orthodox religious events at school. The data reveal that participating in Lutheran religious events at school is mostly described without detectable negative connotations, and the parents' general attitude toward the Lutheran tradition is one of approval. However, the parents' personal feelings differ greatly. One mother, for example, reveals that she is secretly happy knowing that her children always decide not to attend Lutheran events when given the chance to choose. Another mother, being Lutheran herself, recounts an incident in which a substitute teacher did not allow her Orthodox daughter and another child (a Muslim boy) to take part in singing Lutheran hymns but sent them to another room. She states that she gave the teacher furious feedback and insisted that all of the children in the class be present when the Lutheran hymns are sung no matter their religion. 
Encountering the majority religion and their (non-Orthodox) way of life still makes some parents insecure. This is exemplified in Olga's letter. As a mother of two boys, she is afraid that if Orthodoxy's uniqueness is emphasised in RE too strongly, her sons might begin to see it as isolated from the rest of Finnish society, possibly even alienating them from the church. She fears that if something 'unpleasant' (i.e. fasting) is being pushed on the children in the name of religion, they will start to think of Orthodoxy as 'dull and restrictive'. Her sons' realisation of Orthodoxy's divergence from prevailing Finnish way of life can be seen as a potential threat. The potential conflict between Orthodoxy and the general Finnish way of life is a broad phenomenon that is not limited to school and touches many aspects of life.

\subsection{Poor RE arrangements push the religious minority aside in the school and RE teachers cause grief}

Even though half of the parents (20) in my data are happy with RE, there is only one explicit reference to a positive experience with arranging RE: trouble-free forming of the RE group in collaboration with an Orthodox head teacher. The lack of pronounced positive references to practical arrangements for RE does not necessarily mean that parents' general experience of RE is negative; rather, most parents are probably more or less happy with the arrangements for RE and have not encountered hardships worth mentioning. At the same time, there are plenty of references to poorly organised RE. Two main factors have caused them grief: (1) the practicalities in arranging RE, and (2) dissatisfaction with RE teachers.

First, the data reveal that Orthodox RE classes are sometimes unsystematically and incoherently organised. Orthodox pupils may have significantly different curricula and daily rhythms than other, or at least Lutheran, pupils (no references or comparisons to arrangements for other minority RE groups appear in the data). Orthodox RE classes are given, for example, at the end of the week on Friday afternoons and early in the morning, or in some cases even during weekends, when other children are free from school. RE classes can also be irregular. During Lutheran RE lessons, or as a consequence of their special curriculum, the Orthodox pupils may end up with free periods during the school day.

Another problem is the irregularity of RE lessons. The school may, for example, organise other programs for pupils (Orthodox included) at the time that is fixed for Orthodox RE; thus, the children cannot or do not want to attend the RE class. During weeks when there is no Orthodox RE class for one reason or another, in some cases, Orthodox pupils are sent to Lutheran RE instead. In one reported case, the gap between RE classes lasted for several years (the parent did not specify the reasons for this long intermission). If and when Orthodox RE is available, it may require travelling between schools during the day. The following excerpt encapsulates the reality in some families:

Our first child's RE lessons were given as a last lesson on Friday nearly three kilometres from his school. This was not overly motivational for the child, and as a parent, I felt bad sending the small school-goer to traipse, in the worst cases, ten kilometres in one day. (Saara)

This quote illustrates that due to their own RE group, Orthodox pupils may have significantly different curricula and daily rhythms than at least the Lutheran pupils. It is not surprising that parents of Orthodox pupils feel that their children are not necessarily treated equally. Parents who find arrangements for RE problematic emphasise how important it is that Orthodox RE classes are given regularly and at the same time as Lutheran RE. To 
improve the situation, some parents have taken an active role in changing this, such as by contacting the head teacher in order to find a fixed slot for Orthodox RE lessons. References to parents' activity in improving teaching arrangements reveal that attaining appropriate conditions for Orthodox RE may require extra effort, and that schools as obliged organisers of minority RE are not necessarily too keen to fulfil their responsibilities. As an example of the utmost dedication to improving the conditions of Orthodox RE, one mother trained as an RE teacher just to compensate for the weaknesses in RE at school.

Second, the parents sometimes feel that the downsides of RE originate with the teachers. Negative accounts concerning RE teachers are rare in the data, but several parents have experienced RE teachers' behaviour toward their children as unpleasant and the teachers' attitude toward the children as negative: 'Our [children's RE] teachers' problem is, among other things, that not all of them seem to like to teach or like children at all' (Ulla). In some cases, RE teachers' appreciation of their subject is minimal, and the parents had been hoping for a stronger commitment. One such parent, Kaisa, a teacher herself, observes the reality 'from within' the teachers' common room, reporting that many teachers do not appreciate RE but think of it as a useless subject. She also maintains that RE teachers are not enthusiastic about incorporating material symbols (e.g. icons) and expressions of Orthodoxy (e.g. the sign of the cross) into their teaching. They would rather focus more on the theoretical dimension of the subject. Presumably, Kaisa is in favour of tangible and participatory methods of teaching.

The parents' expectations toward RE teachers' personal relation to Orthodoxy varies significantly. The majority of the parents are happy with the example the teachers set of what it means to be Orthodox. Eino, the father of four children, describes his children's RE teacher as 'a brilliant person whose worldview was similar to the one the parents have'. This description is a good representation of how important the teachers' approach is for the parents. Based on the amount and nature of positive feedback given to RE teachers, the vast majority of the parents are grateful for having a good RE teacher for their children. I get the impression from the data that the key element for such contentment lies in the teacher's personality, the resemblance of the parents' and the teacher's approach to Orthodoxy and the supplementary nature of the RE teacher in the overall religious upbringing in the family.

The eminent importance of the parallel between the parents' expectations and the teachers' approach explains why there are parents whom, on the one hand, hope for a stronger commitment from RE teachers, and on the other hand, are disappointed with teachers who are too vigorous or have otherwise tough attitudes. Jutta, for example, is disappointed with her children's RE teachers' unwillingness to understand how binding the apostolic prohibition of eating blood (cf. Acts 15:20, 28-29) is for Orthodox Christians. For 15 years she fought with RE teachers to excuse her children from eating blood pancakes (a famous and perhaps notorious dish in Finnish schools) without success. In quite a different case, another mother (Aila) was so disappointed with the Orthodox RE teacher that she had her children transferred into a Lutheran RE class. The Orthodox RE teacher had insisted on strict fasting from the pupils, he had skipped classes and did not interfere in bullying in the group. She writes that she is happy with the better quality of teaching in the Lutheran RE.

During its 150-year history, there have been constant difficulties in properly organising Orthodox RE (Saine 2000, pp. 109-110). According to Alastalo (2012), the main flaws in Orthodox RE today include scheduling lessons outside of school hours, forming RE groups from pupils from several schools without offering them proper transportation (making it practically impossible for many of them to be on time for classes or to attend them at all) and schools neglecting their legal obligation to organise Orthodox RE altogether. In a survey by Hyvärinen (2014), additional problems include underrated attitudes toward 
Orthodox RE in schools with only a few Orthodox pupils and pressure from a head teacher to send Orthodox pupils to Lutheran RE (in order not to complicate the school's weekly schedule with Orthodox RE).

Similar defects either in organising Orthodox RE lessons reasonably within the regular weekly schedule or offering classes in the first place can also be found in my data. Orthodox RE is a subject that is hard to organise smoothly in many schools, often making it difficult for pupils to attend classes or, in some cases, even building up unsurmountable obstacles to attending.

A survey conducted among Orthodox pupils in 2016 indicates that poor and constantly difficult arrangements for Orthodox RE may have a crucial effect on children's and parents' motivation: inadequate arrangements for RE are the most common reason to opt out of Orthodox RE (Oppilaskysely ortodoksisesta uskonnonopetuksesta 2016). Another study on Finnish children in minority RE groups indicates that even though pupils generally experience RE as positive, age integration, arrangement of schedules, clashing timetables and classroom changes are the most concerning defects for them (Zilliacus and Holm 2013).

In addition, while the majority of the parents were happy with RE teachers and valued their contribution in religious formation, my data reveals that at least some parents saw RE teachers as the culprit in the unsatisfactory RE experience. Similar critical findings towards RE teachers have not been reported in earlier studies on Orthodox RE in Finland. The reasons, at least for criticising theoretically-orientated RE teachers, might originate from the model of Finnish RE: Even though religious rituals can be included in RE as a teaching method, 'confessional' devotion is excluded (see e.g. Kimanen 2015). For another, qualifications for RE teachers are strictly academic. Research by Ubani (2018b) among Finnish Somali parents shows that they nevertheless assume a strong bond between RE and religious formation and judge the suitability of the RE teacher based on his or her religiosity. At least some of the Orthodox parents seem to have similar kinds of expectations.

\subsection{The teacher's example and RE classes foster a positive minority experience}

Becoming aware of one's Orthodox identity is important because something special results from a child's personal observations of the school environment's difference from home and from his or her family environment. Kirsti and Kari, an Orthodox couple and the parents of four children, write that their children were surprised when they became aware that nobody else made the sign of the cross in school and that no Lenten food was offered there during fast days. Further, their children were amazed when they became aware of the existence of the Lutheran church via school, as they had not been familiar with it before this. In contrast, the school may also challenge a child's Orthodox views and beliefs more directly as an external force. As told by Liisa and Hannu, another couple, some of their four children felt disturbed due to their schoolmates' blasphemous comments about God. It seems, then, that children become aware of their Orthodox identity and practices as being different from the norms of the majority due to impulses, reactions and even conflicts arising both from their own observations and from their peers' behaviour.

In the data, the factors in RE contributing to children's identity include the examples their teachers set and forming a positive stance on their religious background. From the parents' perspective, RE teachers play a decisive role in fostering their children's identity as being Orthodox. As many as 13 parents make explicit references to the invaluable support of RE or RE teachers in the religious upbringing of their children. In several of these letters, they mention good teachers by name, with parents recounting stories of 
them giving lessons on 'lifestyle Orthodoxy' mainly just through their great personalities. They depict the teachers as excellent examples of being Orthodox, and the parents consider this to be an important factor in their children's identity formation. An easygoing approach to religion and doing special things as part of RE, like taking the RE group for donuts at the nearby gas station instead of a regular lesson, emerged from the data as concrete expressions of teachers' positive role modelling. Aila encapsulates the focal role of an RE teacher (she describes the teacher in a similar manner as many other parents): 'My children had a good [RE] teacher who was a prominent part of the identity constituting the totality of their education'. In some cases, appreciation of the teachers' role originates either from parents' insecurity about their role as the responsible religious educator or from the lack of other support for their religious parenting.

Third, parents feel that RE contributes to their children's identity by fostering self-esteem and a positive experience of being special. Such effects are positive consequences of minority-majority dynamics, in which Orthodox RE can be defined as a form of societal and communal identity formation. Attending RE in one's own group makes children's minority affiliation concrete in the specific social context of a school environment. Based on the data, attending minority RE classes almost as a necessity leads to an evaluation of one's family, cultural and/or religious heritage.

The society around us nevertheless functions mainly according to the Ev[angelical] Lut[heran] church; thus, cultivating Orthodox identity is in my opinion important. . . . For the most part, my children are proud of their Orthodoxy and everything it involves... (Darja)

The data suggest that the parents believe the Orthodox RE group boosts their children's sense of dignity. Yet, the parents acknowledge that belonging to a minority and the experience of being different can become a burden. The delicate balancing of children's self-evaluation and appreciation of their religious background comes forth in the following description:

Depending on how the other children cope with the 'difference' of the Orthodox child and how she deals with the reactions of other children, the child may begin to feel proud (superior?) of her Orthodoxy. In another situation, the child may react negatively to the attention and want to be just like the others. My own school-goer has in various situations been a proud Orthodox when experiencing being privileged and encountering positive special treatment, admiration or envy. On those occasions, Orthodoxy has been her special thing, just hers! However, she has often wanted to be Lutheran when it is Lent, we have banned Halloween or dressing up as a trulli [a mischievous witch, which is a non-Orthodox Easter tradition] or when arrangements for RE have required going to school earlier than normal. (Elisa)

The school environment clearly enhances the social dynamics of secondary socialisation, especially role-taking in relation to different peer groups and wilfulness to merge with majority peers. In my data, there are accounts of how a lack of feeling of belonging with the majority and the weakness of Orthodox identity within a minority peer group make children question their sense of being in religious minority. For example, two of Heidi's three sons have only one Orthodox classmate, and the third son does not have any. Due to a lack of Orthodox peers and friends, her sons have occasionally wondered why there are no more Orthodox peers. Saara says that the most difficult thing for her has been to explain why her child is the only child in the RE group to attend church. Consequently, cohesion among small numbers of Orthodox peers can also be weak. 


\section{Conclusion and discussion}

The data of this study consist of Finnish Orthodox children's parents' perceptions of how going to school and attending minority RE affect their children's religious and identity formation. The analyses reveal that the parents do not challenge the existing religious, cultural and social order at the schools, which is dominated by the Lutheran tradition. As a rule, they see encountering the Lutheran tradition as a natural thing - an inevitability of Finnish society. Several parents express a willingness to discuss their children's experiences and thoughts on belonging to a religious minority, exposed by the schools, and there are no indications that any of the parents want to avoid such conversations.

The analyses show that parents perceive RE to be important in their children's religious and identity formation. They are, however, far more eager to share their negative experiences with RE than their positive ones. The data give evidence of defects resulting mainly from poor arrangements for Orthodox RE in schools or grief caused by RE teachers' behaviour.

These parents' stories are concrete grass-root-level examples of how the presence of religion in the public sphere of school forces children to enter into discussions of religion's place and its importance in the contexts of their everyday lives-private, public, personal and communal. Negotiating Orthodox identity takes place in the social setting of school and is defined by minority-majority dynamics. Evaluating one's religious, cultural and family traditions potentially fosters identity formation. Yet, feelings of solitude, the experience of being different and a lack of peers with the same religious affiliation are factors that, according to the parents, may add painful tones to the processes of identity construction for Finnish Orthodox children.

In Finland, RE makes pupils' minority (and majority) religious affiliation visible: each pupil gets religious instruction in a group formed according to his or her religious affiliation. It seems that especially the practical arrangements for minority RE contribute to exposure of religious affiliation: for example, moving to another school and attending classes outside of the normal school day concretely locate pupils with minority religious backgrounds into a different space and time than pupils with majority religious backgrounds. Consequently, RE arrangements simultaneously make minority religious groups socially visible (by exposing their 'difference') and invisible (by locating them outside of the 'normal' limits of time and space) from outside, i.e. in and by the school community.

The results of a study by Zilliacus and Holm (2013) show that some pupils in minority RE groups are not familiar with their religious background beforehand-their religious 'identity' is revealed to them in their RE class. An identity assumption in Finnish RE, as Kimanen (2015) defines it, serves the purpose of fostering the pupil's communal identity. Assumptions are manifested, for example, in the teaching material when pupils are assumed to have personally experienced rituals and religious practices. This actually conflicts with the idea of the national curriculum that minority RE aims to strengthen and maintain religious identity rather than create it. Offering religious instruction based on denominational membership does not necessarily address pupils' actual identities. Some parents in my data express insecurity in relation to their own Orthodox identity and religious parenting (see Metso 2018); nevertheless, there are no references to an absence or lack of awareness of Orthodox identity among the parents, and consequently, perhaps, among their children.

Making children's minority religious affiliation known to the class and to the school (and perhaps to the children themselves) is not, obviously, necessarily a bad thing. Parents expect Orthodox RE to enhance their children's self-esteem and appreciation of their own 
religious and cultural heritage, consequently conforming to the focal aim of Orthodox RE. In minority RE groups, reflecting, discussing and interpreting experiences arising from the specific societal minority context helps pupils to understand the importance of religion to themselves personally as well as to see from a minority perspective how religion influences their surrounding society and culture. In other words, RE is a means of making Orthodox beliefs and minority identity visible for the pupils in attendance, thus fostering their identity formation from within, in a group formed by peers and a teacher of the same faith.

This study focuses on parents' ideas, convictions and experiences regarding what they know and believe to take place in their children's schools. Research among pupils in minority RE groups in Finland has shown that children of minority religions aim to conceal their religious heritage from their peers. For example, pupils in Muslim, Orthodox and Jewish RE tend to conceal the fact that they attend minority RE class and keep silent about what happens in their RE classes (Zilliacus and Holm 2013). Similar observations did not emerge from my data but have been recognised in relation to Orthodox RE in previous research (Berglund 2014). There is no reason not to believe that at least some children of the parents involved in my study conceal their minority religious identities from their peers. This prompts the question, how well do parents conceive of the complexity of their children's experience of identity, and in what ways do they navigate between their roles in the classroom and in their daily lives.

Acknowledgements Open access funding provided by University of Eastern Finland (UEF) including Kuopio University Hospital.

OpenAccess This article is distributed under the terms of the Creative Commons Attribution 4.0 International License (http://creativecommons.org/licenses/by/4.0/), which permits unrestricted use, distribution, and reproduction in any medium, provided you give appropriate credit to the original author(s) and the source, provide a link to the Creative Commons license, and indicate if changes were made.

\section{References}

Aikonen, R. (2012). What is the purpose of religious education in the Finnish context? Greek Orthodox Theological Review, 57(1-4), 63-79.

Alastalo, S. (2012). Ministeriö puuttuu ortodoksisen uskonnonopetuksen ongelmiin. Kotimaa24. Retrieved September 24, 2018 from https://www.kotimaa24.fi/artikkeli/ministerio-puuttuu-ortodoksisen-uskon nonopetuksen-ongelmiin/.

Alitolppa-Niitamo, A. (2002). The generation in-between: Somali youth and schooling in metropolitan Helsinki. Intercultural Education, 13(3), 275-290. https://doi.org/10.1080/1467598022000008350.

Berglund, J. (2010). Teaching Islam: Islamic religious education in Sweden. Münster: Waxmann.

Berglund, J. (2014). Teaching Orthodox religious education on the border. British Journal of Religious Education, 36(3), 282-297. https://doi.org/10.1080/01416200.2014.902805.

Dupper, D., Forrest-Bank, S., \& Lowry-Carusillo, A. (2015). Experiences of religious minorities in public school settings: Findings from focus groups involving Muslim, Jewish, Catholic, and Unitarian Universalist Youths. Children \& Schools, 37(1), 37-45. https://doi.org/10.1093/cs/cdu029.

Esitys perusopetus- ja lukiolain muuttamisesta. (2014). Hallituksen esitys eduskunnalle laeiksi perusopetuslain 13 §:n ja lukiolain 9 §:n muuttamisesta. Retrieved September 24, 2018 from https://www.finle x.fi/fi/esitykset/he/2014/20140136.

Forrest-Bank, S., \& Dupper, D. (2016). A qualitative study of coping with religious minority status in public schools. Children and Youth Services Review, 61, 261-270. https://doi.org/10.1016/j.childyouth .2015.12.025.

Franken, L., \& Loobuyck, P. (Eds.). (2011). Religious education in a plural, secularised society. A paradigm shift. Münster: Waxmann. 
Hemming, P., \& Madge, N. (2012). Researching children, youth and religion: Identity, complexity and agency. Childhood, 19(1), 38-51. https://doi.org/10.1177/0907568211402860.

Huttunen, H. (2018). Pohdintoja uskonnonopetuksen asemasta. Ortodoksinen opettaja, 1(2018), 10-11.

Huurinainen-Kosunen, A., \& Lyhykäinen, K. (s.a.). Ortodoksinen uskonto. Retrieved September 24, 2018 from https://www.edu.fi/perusopetus/uskonto_ja_elamankatsomustieto/ortodoksinen_uskonto [and subpages].

Hyvärinen, E. (2014). Vanhempien käsityksiä ja kokemuksia ortodoksisen uskonnon opetuksesta. Näkökulmia uskonnon oppiaineen kehittämiseen. Unpublished master's theses. Tampere: University of Tampere.

Iivonen, P. (2009). Muistio perusopetuksen yleisten tavoitteiden ja tuntijaon työryhmälle. Retrieved September 17, 2018 from https://www.oph.fi/download/118443_Uskonnon_muistio_tyoryhmall e_16122009.pdf.

Jäggle, M., Rothgangel, M. \& Skeie, G. (Eds.) (2014). Religious education at schools in Europe, Part 3: Northern Europe. Göttingen: V\&R Unipress.

Kallioniemi, A., \& Ubani, M. (2012). Religious education in Finnish school system. In H. Niemi, A. Toom, \& A. Kallioniemi (Eds.), Miracle of education: The principles and practices of teaching and learning in Finnish schools (pp. 177-188). Rotterdam: Sense Publishers.

Kimanen, A. (2015). Complicated confessionality: How the concept of 'confessionality' could serve the debate on religious education better? Journal of Religious Education, 63(2-3), 129-140. https:// doi.org/10.1007/s40839-016-0031-3.

Korkeakoski, K., \& Ubani, M. (2018). What positive things do students from different backgrounds see in integrated RE lessons with collaborative teaching? Three cases from a Finnish teaching experiment. Journal of Religious Education, 66(1), 49-64. https://doi.org/10.1007/s40839-018-0056-x.

Laitila, T. (2008). Suspicion, négligence et respect: les relations entre l'Églige luthéranne et l'Église orthodoxe en Finlande après la Seconde guerre modiale. Istina, 53(4), 365-379.

Leo, archbishop. (2010a). Uskonnonopetus monikulttuurisuuden rakentajana. Retrieved September 24, 2018 from http://www.ekumenia.fi/sen_toimii/kasvatus_ja_ekumenia/arvot_mekin_ansaitsemm e_5-632010/arkkipiispa_leo_uskonnonopetus_monikulttuurisuuden_rakentajana/.

Leo, archbishop. (2010b). Uskonto on arvoja. Retrieved September 24, 2018 from https://ort.fi/arkki piispa/kolumnit-ja-kannanotot/uskonto-arvoja.

Leo, archbishop. (2012). Aitoa monikulttuurisuutta uskonnonopetukseen. Retrieved September 24, 2018 from https://ort.fi/arkkipiispa/kolumnit-ja-kannanotot/aitoa-monikulttuurisuutta-uskonnonopetuks een.

Leo, archbishop. (2015). Uskonnonopetusta turvaamaan ja uudistamaan. Retrieved September 24, 2018 from http://www.ekumenia.fi/etusivu/ajankohtaista_-_aktuellt/arkkipiispa_leo_uskonnonopetust a_turvaamaan_ja_uudistamaan/.

Loikala, M. (2015). Ortodoksisen uskonnon opetuksen ja ortodoksikristillisen koulun perustamisen merkitys vanhemmille. Unpublished bachelor's theses. Helsinki: The Diaconia University of Applied Sciences.

Lyhykäinen, K. (2009). The aims of Orthodox religion teachers. In C. Bakker, H.-G. Heimbrock, R. Jackson, G. Skei, \& W. Weisse (Eds.), Religious diversity in education: Nordic perspectives (pp. 197-206). Münster: Waxmann.

Lyhykäinen, K., \& Smalin, T. (2008). Pääkaupungin ortodoksiset yläkoululaiset pitävät tärkeänä oman uskonnon opetusta. Ortodoksiviesti, 8(2008), 11.

Metso, P. (2018). Raising a Christian or an Orthodox Christian? Parents' experience of their ecumenical reality and minority status in religious upbringing of Finnish Orthodox children and youth. In M. Ubani (Ed.), New international studies on religions and dialogue in education (pp. 13-30). Münster: Waxmann.

Ministry for Foreign Affairs. (2010). Religion lessons support kids' identities. Retrieved September 17, 2018 from https://finland.fi/life-society/religion-lessons-support-kids-identities/.

National Framework Curriculum. (2014). Helsinki: Opetushallitus. [Perusopetuksen opetussuunnitelman perusteet in Finnish].

Okulov, S. (2011). Oman uskonnonopetuksen rooli monikulttuurisessa yhteiskunnassa. In M. Kantonen (Ed.), Tarhurit 2011 (pp. 189-199). Hämeenlinna: Suomen Ortodoksisten Opettajien Liitto.

Okulov, S. (2014). Uskonnonopetus tarvitsee lisätunteja. Simeon ja Hanna, March 11 2014. Retrieved September 24, 2018 from https://simeonjahanna.com/2014/11/11/uskonnonopetus-tarvitsee-lisatunteja/.

Oman uskonnon opetus. (2018). Retrieved September 24, 2018 from https://ort.fi/tutustu-ortodoksiseenkirkkoon/oman-uskonnon-opetus.

Oppilaskysely ortodoksisesta uskonnonopetuksesta. (2016). Retrieved September 24, 2018 from https:// ort.fi/uutishuone/2016-02-01/oppilaskysely-ortodoksisesta-uskonnonopetuksesta-0. 
Pessi, A., \& Pöyhönen, P. (2010). Yksilön, perheen ja kirkon yhteiskunnalliset muutoslinjat - valintojen ja rakkauden hurma. In A. Pessi \& H. Grönlund (Ed.), Perhe, parisuhde ja kirkko. Lähikuvia leikkauspintoihin (pp. 12-40). Helsinki: Helsingin yliopisto, Käytännöllisen teologian laitos.

Rissanen, I. (2014). Negotiating identity and tradition in single-faith religious education: A case study of Islamic religious education in Finnish schools. Münster: Waxmann.

Saine, H. (2000). Uskonnonopetus Suomen oppivelvollisuuskoulussa 1900-luvulla. Turku: Turun yliopisto.

Sakaranaho, T. (2006). Religious freedom, multiculturalism, Islam: Cross-reading Finland and Ireland. Leiden: Brill.

Sakaranaho, T. (2007). Pienryhmäisten uskontojen opetus ja uskonnonvapaus. Teologia.fi 1/2007. Retrieved September 17, 2018 from https://www.teologia.fi/tutkimus/uskontojen-valiset-suhteet/60-pienryhmte n-uskontojen-opetus.

Sakaranaho, T. (2008). Islam ja muuttuva katsomusaineiden opetus koulussa. In T. Martikainen, T. Sakaranaho, \& M. Juntunen (Eds.), Islam Suomessa (pp. 157-181). Helsinki: Suomalainen kirjallisuuden seura.

Sakaranaho, T. (2018). Encountering religious diversity: Multilevel governance of Islamic education in Finland and Ireland. Journal of Religious Education, 66(2), 111-124. https://doi.org/10.1007/s4083 9-018-0065-9.

Torstenson-Ed, T. (2006). Children and God in the multicultural society. British Journal of Religious Education, 28(1), 33-51. https://doi.org/10.1080/01416200500343118.

Tuutti, O., \& Vainio, D. (2007). Venäläisten maahanmuuttajalasten kokemuksia ortodoksisen uskonnon opetuksesta. In T. Sakaranaho \& A. Jamisto (Eds.), Monikulttuurisuus ja uudistuva katsomusaineiden opetus (pp. 211-222). Helsinki: Helsingin yliopisto.

Ubani, M. (2013a). Threats and solutions. Multiculturalism, religion and educational policy in Finland. Intercultural Education, 24(3), 195-210. https://doi.org/10.1080/14675986.2013.797701.

Ubani, M. (2013b). Peruskoulun uskonnonopetus. Jyväskylä: PS-kustannus.

Ubani, M. (2018a). Do students feel authentic in integrated RE? A quantitative analyses. International Journal of Children's Spirituality, 23(2), 152-179. https://doi.org/10.1080/1364436X.2018.1448759.

Ubani, M. (2018b). When teachers face religion in public education. Case examples from Finnish public education. Journal of Religious Education, 66(2), 139-150. https://doi.org/10.1007/s4083 9-018-0064-x.

Ubani, M., \& Ojala, E. (2018). Introduction. Journal of Religious Education, 66(2), 79-83. https://doi. org/10.1007/s40839-018-0067-7.

Uskonnonopetus kouluissa. (2018). Retrieved September 24, 2018 from https://ort.fi/kasvatus-ja-koulutus/ uskonnonopetus-kouluissa.

Uskonnonopetus Suomessa. (2016). https://suol.fi/index.php/uskonnonopetus-suomessa/uskonnonopetussuomessa. Retrieved 24 September 2018.

Vatanen, S. (2000). Kohtaavatko koti ja ortodoksisuus?: Vanhempien käsityksiä uskontokasvatuksesta Joensuun ja Taipaleen ortodoksisissa seurakunnissa. Unpublished master's theses. Joensuu: Joensuun yliopisto.

Yhteinen katsomusopetus ei saa kannatusta. (2015). Retrieved September 24, 2018 from https://ort.fi/uutis huone/2015-08-17/yhteinen-katsomusopetus-ei-saa-kannatusta.

Åhs, V., Poulter, S., \& Kallioniemi, A. (2019). Preparing for the world of diverse worldviews: Parental and school stakeholder views on integrative worldview education in a Finnish context. British Journal of Religious Education, 41(1), 78-89. https://doi.org/10.1080/01416200.2017.1292211.

Zilliacus, H. (2013). Addressing religious plurality: A teacher perspective on minority religion and secular ethics education. Intercultural Education, 24(6), 507-520. https://doi.org/10.1080/14675 986.2013.867761.

Zilliacus, H. (2014). Supporting students' identities and inclusion in minority religious and secular ethics education: A study on plurality in the Finnish Comprehensive School. Helsinki: Helsingin yliopisto.

Zilliacus, H., \& Holm, G. (2013). 'We have our own religion': A pupil perspective on minority religion and ethics instruction in Finland. British Journal of Religious Education, 35(3), 282-296. https://doi. org/10.1080/01416200.2012.750707.

Publisher's Note Springer Nature remains neutral with regard to jurisdictional claims in published maps and institutional affiliations. 